\title{
Importance of water level dynamics for vegetation patterns in a natural percolation mire (Rospuda fen, NE Poland)
}

\author{
Ewa Jabłońska • Paweł Pawlikowski • \\ Filip Jarzombkowski · Jarosław Chormański • \\ Tomasz Okruszko $\cdot$ Stanisław Kłosowski
}

Published online: 19 May 2011

(C) The Author(s) 2011. This article is published with open access at Springerlink.com

\begin{abstract}
Although conservation of percolation mires is very important for the European biodiversity, our understanding of their functioning is still insufficient, as most of the studied sites are to some extent degraded. We present a study on the relationship between vegetation patterns, hydrochemical gradients and water level fluctuations carried out in the Rospuda valley (NE Poland), which was recently discovered for science as a uniquely preserved fully functioning percolation mire. Vegetation composition, mire water chemistry and water level dynamics were studied along five transects perpendicular to the valley. Eight major vegetation types were identified: brown moss-small and slender sedge fens, Sphagnum-small sedge fens,
\end{abstract}

Guest editors: Dominik Zak, Robert McInnes, Jörg Gelbrecht / Restoration, biogeochemistry and ecological services of wetlands

E. Jabłońska $(\bowtie) \cdot$ P. Pawlikowski · S. Kłosowski Department of Plant Ecology and Environmental Conservation, University of Warsaw, Al. Ujazdowskie 4, 00-478 Warsaw, Poland

e-mail: e.jablonska@uw.edu.pl

F. Jarzombkowski

Department of Nature Protection in Rural Areas, Institute of Technology and Life Sciences, Al. Hrabska 3 Falenty, 05-090 Raszyn, Poland

J. Chormański · T. Okruszko

Subdepartment of Hydrology and Water Resources, Warsaw University of Life Sciences, ul. Nowoursynowska 159, 02-787 Warsaw, Poland brown moss-tall sedge fens, tall sedge-reed fens, pinebirch fen woodlands and shrublands, spruce fen woodlands, inundated alder woodlands, alder spring fen woodlands. The seasonal dynamics of water table was revealed as the major factor explaining vegetation patterns. The studied chemical parameters were relatively homogeneous in the whole mire-there is a rather uniform type of mineral-rich nutrient-poor subsurface water all across the fen.

Keywords Brown moss-small sedge vegetation · Rich fen · Rospuda valley · Vegetation zonation . Water chemistry · Water level dynamics

\section{Introduction}

Percolation mires are a characteristic peatland type of the (sub)continental sections of the temperate zones of the world. However, as the temperate zone is worldwide the zone with the most intensive human impact, most percolation mires in this zone have been reclaimed and irreversibly destroyed or severely damaged (Succow \& Joosten, 2001) because of their suitability for agriculture (calcareous, nutrient rich meadows after drainage; water availability in the somewhat dry (sub)continental regions), and the relative ease with which they can be drained. In temperate Europe one of few remaining, well-preserved percolation mires is the Rospuda fen in northeastern Poland. Merely any human impact has been 
observed within the river valley that bares no signs of drainage and has only locally been extensively managed by farmers and forestry. Moreover, atmospheric $\mathrm{N}$ deposition is decisively lower here than in western

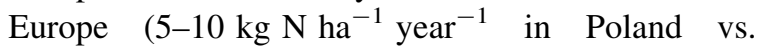
$50 \mathrm{~kg} \mathrm{~N} \mathrm{ha}^{-1}$ year $^{-1}$ in the Netherlands) (Verhoeven et al., 1996), especially that the north-eastern part of Poland is hardly urbanized and industrialized.

During the last several years some detailed geobotanical and ecohydrological research was carried out in the Rospuda river valley in order to document the characteristics of this ecosystem (e.g. Pawlikowski, 2008). The results confirmed that the Rospuda valley supports groundwater-fed, well preserved percolation fens, which have the following features: (1) a sloping surface from the mire margin to the river; (2) a rather thick (180-300 cm) layer of very uniform, little decomposed, and highly hydraulically conductive sedge-brown moss peat, that enables water to move slowly ("percolate") through the peat body from the mire margin to the river; (3) constant water saturation; (4) bicarbonate and cation-rich water $\left(\mathrm{Ca}^{2+} 2-50 \mathrm{mg} \mathrm{l}^{-1}, \mathrm{Mg}^{2+} 2-24 \mathrm{mg} \mathrm{l}^{-1}\right)$ that confirms its groundwater origin; (5) mesotrophic (or even oligo-mesotrophic in certain areas) conditions that favour poorly competitive species; (6) large areas of open, brown moss-rich mire vegetation; (7) clearly marked zonation of vegetation.

In natural percolation mires, the favourable hydraulic, hydrological and hydrochemical conditions slow down successional processes and support stable open low-productive vegetation, offering unique habitat for endangered and protected plant species. Even small-scale drainage can destroy this balance, leading to eutrophication, acidification and changes in species composition. A typically observed phenomenon is the expansion of shrub and tree cover after drainage, which makes typical fen species dependent on active conservation measures, such as shrub cutting and mowing (Van Diggelen et al., 2006). As natural percolation mires can hardly be restored, the prime aim must be to protect the few remaining ones, also to know what the final aim of restoration efforts at other sites is.

The factors determining mire vegetation patterns are often addressed as gradients, originally defined by Du Rietz (1949) as "directions of variations" (e.g. Malmer, 1986; Wheeler \& Proctor, 2000). The most important ones are: poor-rich gradient, standing for base and carbonate richness; mire margin-mire expanse gradient; fertility gradient, i.e. gradient of liming nutrient (usually $\mathrm{N}$ and $\mathrm{P}$ ) availability and water level gradient.

The relative importance and role of individual gradients in determining mire vegetation patterns has been widely discussed. Most studies indicate that the poor-rich gradient determines (Wheeler \& Proctor, 2000; Økland et al., 2001) or co-determines (Sjörs, 1950; Malmer, 1986) vegetation patterns. Recently, some authors (e.g. Hájková \& Hájek, 2004; Bragazza et al., 2005) underlined the interplay of the poorrich gradient with the hydrological gradient as the major mechanism explaining the diversity of mire vegetation.

The aim of this article is to specify the influence of hydrochemical factors and water level dynamics on spatial vegetation patterns of a natural percolation mire and to assess the relative importance of gradients formed by these factors.

\section{Materials and methods}

Study area

The Rospuda river valley mire is located in NE Poland (Fig. 1), in the Lithuanian Lake District (Kondracki, 2001). The mire has developed in a deep post-glacial channel partly filled with sander sands. Although the catchment is in a significant part agriculturally used, the surrounding forest forms a buffer zone which limits the influence of agricultural land.

The study was conducted on a mire in the southern part of the Rospuda valley, between the bridge near Młynisko site and Rospuda Lake. Five transects perpendicular to the valley, extending from the valley margin to the river (Fig. 1), covered full range of vegetation zonation both across and along the valley mire. Twenty seven piezometers were installed along the transects in plant communities of distinct physiognomy and species composition.

Eight main vegetation types (Fig. 1) were distinguished on the basis of detailed vegetation survey (Pawlikowski et al., 2010) and TWINSPAN analyses of 380 phytosociological relevés from the whole Rospuda mire. The five transects and sampling plots along the transects were chosen to represent all the 


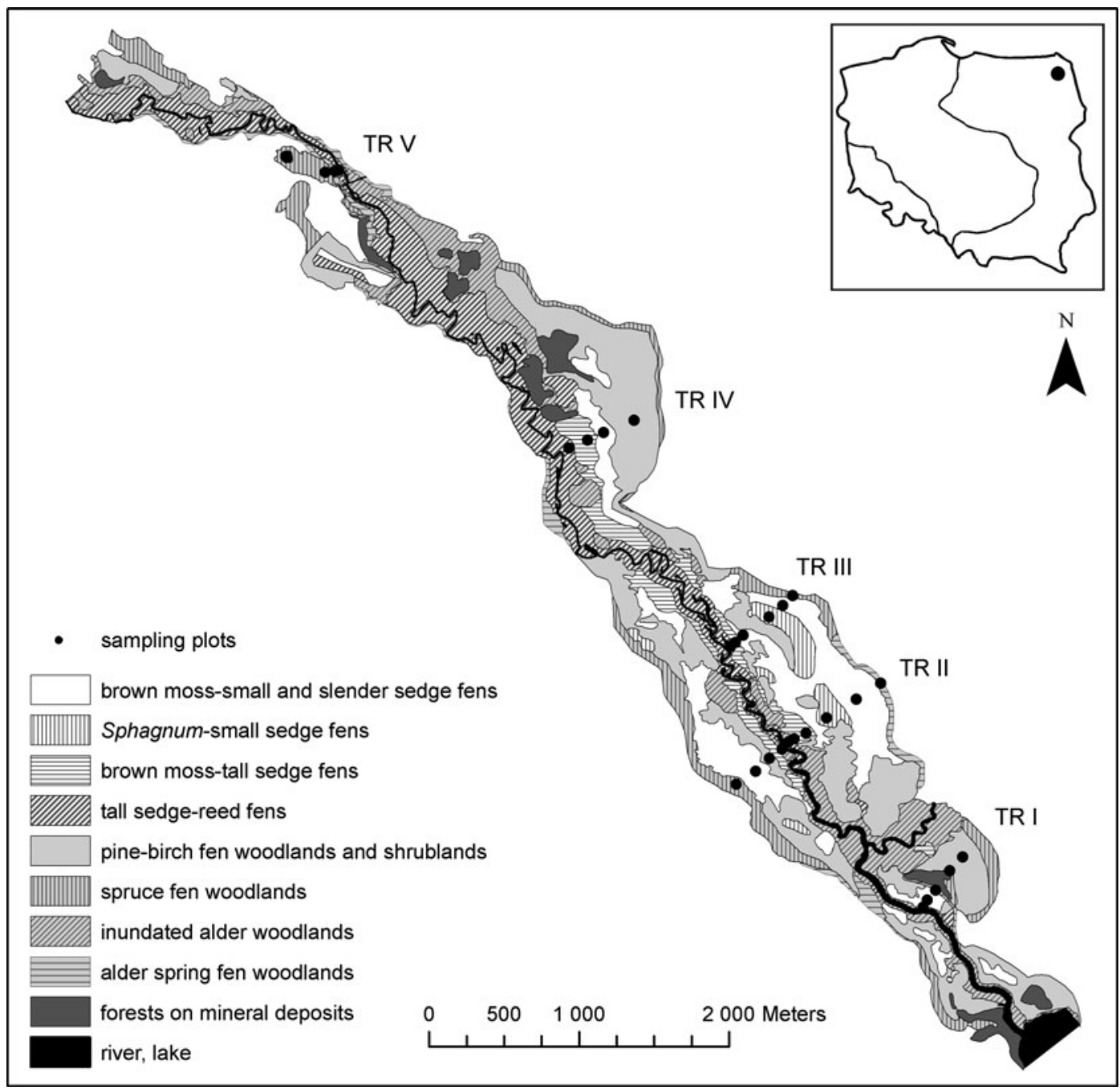

Fig. 1 Location of the Rospuda valley and schematic vegetation map with sampling sites. TR I, TR II, TR III, ... names of sampling transects

eight vegetation types, which are (number of relevés in each vegetation type included in this study in brackets):

(1) Brown moss-small and slender sedge fens (6 relevés) - form a broad (in the main mire basin) or a narrow (other mire parts) zone between (3) and (5) or (8). This low-productive and bryophyte-rich vegetation is rather diverse and varies between various mire parts. There are few dominants widespread in the whole zone; these are Menyanthes trifoliata, Carex rostrata, Carex lasiocarpa, Thelypteris palustris and Calliergonella cuspidata. In the main mire basin, the most important species include Hamatocaulis vernicosus, Tomentypnum nitens, Festuca rubra, Carex diandra, while in the other mire parts Limprichtia cossonii, Campylium stellatum, Carex appropinquata and C. elata can be prominent. This zone supports the majority of endangered fen species, such as Saxifraga hirculus, Liparis loeselii, Dactylorhiza incarnata ssp. ochroleuca, Carex chordorrhiza, Eriophorum gracile, Paludella squarrosa and many others.

(2) Sphagnum-small sedge fens (2 relevés)develop in certain areas in the southern part of 
the mire (the main mire basin), forming a discontinuous zone within the middle of (1). The vegetation is dominated by Sphagnum teres, Sph. angustifolium, Oxycoccus palustris and M. trifoliata. Many rich fen species typical for the (1) zone are abundant, e.g. Carex dioica, $C$. rostrata, C. chordorrhiza, C. limosa and $F$. rubra.

(3) Brown moss-tall sedge fens (4 relevés)—form a rather narrow zone between (1) and (4) or (7). They are intermediate between low-productive, bryophyte-rich small sedge fens and rather highproductive, bryophyte poor tall sedge-reed communities and dominated by $C$. appropinquata, C. rostrata, C. lasiocarpa, M. trifoliata, T. palustris and Phragmites australis. In moderately developed moss layer $C$. cuspidata and Plagiomnium species are the most prominent.

(4) Tall sedge-reed fens (4 relevés) - form a discontinuous zone adjacent to the river. This highproductive, species-poor zone is dominated by P. australis and Carex acutiformis; Phalaris arundinacea is abundant in certain areas. Bryophytes are hardly present.

(5) Pine-birch fen woodlands and shrublands (3 relevés) - usually form a zone between (1) and (6) and also woodland or shrubland islands within (3) in certain areas. This species- and bryophyte-rich vegetation is rather diverse and includes nearly pure pine- or birch-dominated stands, pine-birch woodlands with abundant presence of alder or spruce, low "dwarf" forests with pine, birch and juniper, and shrublands with various birch (Betula pubescens, B. humilis) and willow (Salix rosmarinifolia, S. myrsinifolia, $S$. cinerea) species. The herb layer is very diverse, but most prominent species include $M$. trifoliata, T. palustris, $P$. australis, C. appropinquata, Carex cespitosa, C. acutiformis, O. palustris, and Equisetum fluviatile. The very species-rich moss layer is formed by numerous sphagna (e.g. Sphagnum palustre, Sph. teres, Sph. squarrosum, Sph. capillifolium), C. cuspidata, Pleurozium schreberi, Hylocomnium splendens and various Mnium s.l. species. Some species typical of open fens (such as C. dioica, C. stellatum or even orchids) are abundant in certain areas. This vegetation zone supports many rare wetland forest species, such as Malaxis monophyllos, Corallorhiza trifida,
Baeothryon alpinum, Trisetum sibiricum and Helodium blandowii.

(6) Spruce fen woodlands (2 relevés)—form a discontinuous zone adjacent to the valley margin, neighbouring (5) zone. This spruce-dominated forest (usually with some pine, birch and alder) has dense, species-rich mosses and liverworts layer dominated by sphagna (predominantly Sphagnum palustre), H. splendens and $P$. schreberi. The herb layer is rather uniform, with Vaccinium myrtillus, Lycopodium annotinum, C. cespitosa being the most abundant species.

(7) Inundated alder woodlands (3 relevés) - form a discontinuous, usually narrow (but broad in certain areas in the northern part of the mire) zone, usually adjacent to the river. In this alderdominated, rather species-poor forest, bryophytes are usually hardly present. The abundant herb layer is dominated by C. acutiformis, C. cespitosa and P. australis.

(8) Alder spring fen woodlands (3 relevés)—form a narrow, discontinuous zone usually adjacent to the valley margin. This alder-dominated forest has abundant herb layer with $C$. acutiformis, Crepis paludosa and Chrysosplenium alternifolium. The moss layer is moderately developed and is dominated by Plagiomnium species (mainly $P$. undulatum).

Sampling procedure and analyses

Research was carried out for 2 years (2007-2008). The installed piezometers were filtered at $0.35-0.5 \mathrm{~m}$ segment below mire surface. Water level was measured in all the piezometers in 15-days intervals. Water samples were collected from each piezometer three times during the growing season of 2007 (May, July, September). The piezometers were first emptied and the water samples were collected after several hours when the piezometrs filled again with water. The water was analysed for: $\mathrm{pH}$ (using portable $\mathrm{pH}$ meter), carbonate hardness by Warthy-Pfeifer method, $\mathrm{PO}_{4}{ }^{3-}$ spectrophotometrically by molybdate method, $\mathrm{NO}_{3}{ }^{-}$ spectrophotometrically with phenoldisulphonic acid, $\mathrm{NH}_{4}{ }^{+}$spectrophotometrically by Nessler's method, $\mathrm{SO}_{4}{ }^{2-}$ spectrophotometrically by the nephelometric method, total $\mathrm{Fe}$ spectrophotometrically by the 
rhodanate method, dissolved $\mathrm{SiO}_{2}$ spectrophotometrically by the molybdate method, $\mathrm{Cl}^{-}$by Mohr method, $\mathrm{Mg}^{2+}$ with atomic absorption spectrophotometer, $\mathrm{Ca}^{2+}, \mathrm{K}^{+}$and $\mathrm{Na}^{+}$with a flame spectrophotometer (concentrations of $\mathrm{K}^{+}$and $\mathrm{Na}^{+}$were determined in $100 \mathrm{ml}$ solutions extracted with $2 \mathrm{ml} \mathrm{HCl}(1+1)$ from evaporated and ignited $100 \mathrm{ml}$ samples of water). The samples for $\mathrm{NO}_{3}{ }^{-}, \mathrm{NH}_{4}{ }^{+}, \mathrm{PO}_{4}{ }^{3-}$ and $\mathrm{Fe}_{\text {total }}$ analyses were conserved by adding $1 \mathrm{ml} \mathrm{H}_{2} \mathrm{SO}_{4}$ per 11 of the sample.

A phytosociological relevé $(5 \times 5 \mathrm{~m}$ in non-forest vegetation, $10 \times 10 \mathrm{~m}$ in woodlands) was made at the location of each of the 27 piezometers, using the classic Braun-Blanquet (1951) method. Taxonomic names follow Mirek et al. (2002) for vascular plants and Ochyra et al. (2003) for mosses. The total cover of both shrub and tree layers was used as a measure of shading.

The mire surface was levelled along two transects (TR II and TR IV)—in forested areas using a classic method, in non-forest vegetation using a Differential GPS-Real Time Kinematic method.

Moreover, some previously collected data on $\mathrm{pH}$ and electrical conductivity (EC) values as well as $\mathrm{Ca}^{2+}$ and $\mathrm{Mg}^{2+}$ concentrations in surficial waters in mire non-forest vegetation-brown moss-small and slender sedge fens and Sphagnum-small sedge fens (Pawlikowski, 2008) were used in the present analyses. Chemical analyses were carried out using the methods mentioned above.

\section{Data processing}

The relationships between species composition of vegetation types were analysed by indirect ordination in CANOCO for Windows Version 4.0 (Ter Braak \& Šmilauer, 1998). Indirect ordination methods were also used to choose between unimodal and linear ordination methods on the base of lengths of gradient (Detrended Correspondence Analysis, DCA) and in search of arch-effect and outliers (Correspondence Analysis, CA).

At each piezometer, chemical parameters were expressed by medians from three measurements (May, July, September), whereas water level dynamics was characterised by its minimum, maximum, average and amplitude over the whole study period, as well as minimum and maximum levels from 2-month periods (March-April, May-June, JulyAugust, September-October) during 2 years.

The relationship between habitat factors and vegetation was analysed by direct ordination in CANOCO for Windows v. 4.0 (Ter Braak \& Šmilauer, 1998). As the length of gradient in DCA exceeded 4 SD (compare Fig. 2) —CCA was used. To avoid using strongly correlated variables in CCA, those with the variance inflation factor $>20$ were removed from the analysis one after another (cf. Ter Braak, 1986). The significance of CCA was tested with Monte-Carlo permutation test. Permutation type was restricted for spatial structure (line transects).

Additional data on $\mathrm{pH}, \mathrm{EC}, \mathrm{Ca}^{2+}$ and $\mathrm{Mg}^{2+}$ in surficial waters in the non-forest mire vegetation were analysed using indirect ordination in CANOCO for Windows. PCA was used because the length of gradient in DCA did not exceed 2 SD.

\section{Results}

Twenty seven phytosociological relevés (several from each vegetation type) were divided into quite distinct groups in DCA (Fig. 2), which confirmed that the sampling points represented well-distinguished and ecologically separate vegetation types. The first axis separates relevés representing spruce and pine-birch fen woodlands from relevés made within other plant communities. The second axis distinguishes in particular relevés from brown moss-tall sedge and tall sedge-reed communities from those made within Sphagnum-small sedge vegetation. The relevés recorded within brown moss-small and slender sedge communities are located in the middle of the second axis gradient.

CCA with vegetation and environmental data (Fig. 3) also shows distinctness of all the vegetation types. Environmental variables used in CCA explain over $73 \%$ of the analysed vegetation diversity (4.276/ $5.843 \times 100 \%$; Table 1). All four water level dynamic variables included in the ordination analysis, as well as $\mathrm{Mg}^{2+}, \mathrm{SiO}_{2}$ and shrub/tree cover, were correlated with first axis with $r>0.5$. In the case of second ordination axis only $\mathrm{Fe}$ was correlated with $r>0.5$ (Table 1).

The lowest minimum summer water level is related to spruce fen woodlands, pine-birch fen woodlands and Sphagnum-small sedge communities (Fig. 3). These three vegetation types have a relatively stable low 
Fig. 2 Detrended correspondence analysis of vegetation relevés from the transects in the Rospuda valley. Eigenvalues: I, 0.769; II, 0.587; III, 0.379; IV, 0.214. Lengths of gradient: I, 5.603; II, 5.669; III, 3.270; IV, 3.519

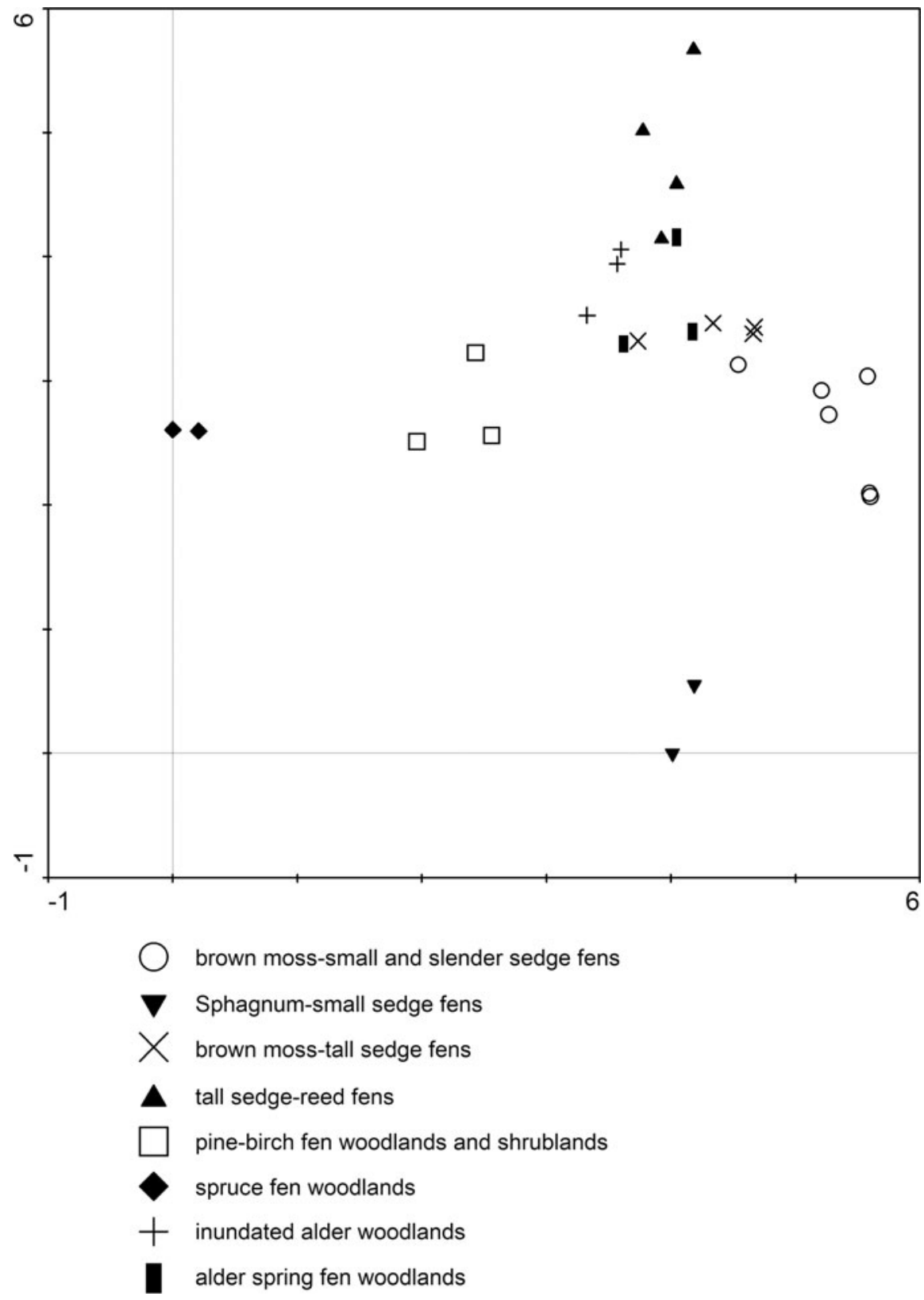

groundwater level throughout the year (Table 2). The highest spring and autumn maximum water level characterises the tall sedge-reed fens and alder woodlands (Fig. 3; Table 2). Brown moss-small and slender sedge fens and brown moss-tall sedge fens are characterised by the lack of either extremely low water levels during summer or very high water level in the spring (Fig. 3). They have relatively constant water table close to the peat surface throughout the year (Table 2). Vegetation type 3 (brown moss-tall sedge fens) is characterised by similar water level dynamics as vegetation type 1 (brown moss-small and slender sedge fens) but with slightly larger amplitude, due to higher maximum levels in the spring and lower minimum during early summer. Water level fluctuations in particular zones including absolute level values are presented in Fig. 4.

The chemical composition of subsurface water is rather uniform within the whole mire area (Table 2); therefore the differences in the chemical properties 
Fig. 3 Canonical correspondence analysis biplot for relevés, chemical factors and water level dynamics parameters. III, $\mathrm{IV}, \ldots, \mathrm{X}=$ March, April, ..., October. Minimum water level is expressed by negative values for clarity. Eigenvalues: I, 0.696; II, 0.539; III, 0.468; IV, 0.354 . See Table 1 for detailed summary of the model results

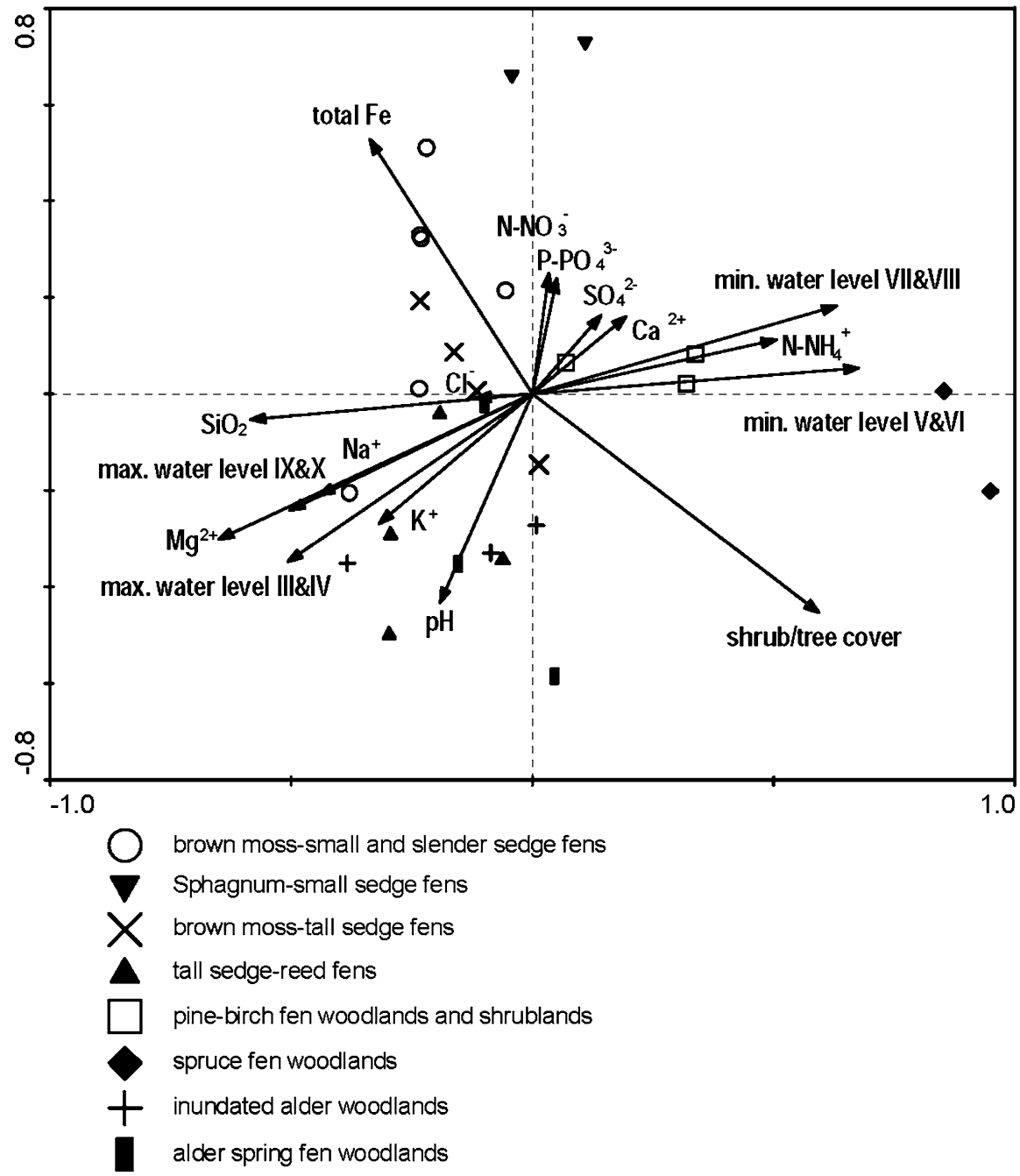

between the vegetation types, except for $\mathrm{Mg}^{2+}, \mathrm{SiO}_{2}$, and $\mathrm{Fe}_{\text {tot }}$ concentrations, are usually rather small (Fig. 3). Vegetation types rich in $\mathrm{SiO}_{2}$ and $\mathrm{Mg}^{2+}$ are also characterised by high water levels. Spruce- and pine-birch fen woodlands have the lowest concentration of these elements. $\mathrm{Mg}^{2+}$ is a bit more than $\mathrm{SiO}_{2}$ correlated with the second axis of ordination (Table 1). Differences in the concentration of $\mathrm{Mg}^{2+}$ between vegetation type 1 (brown moss-small and slender sedge fens) and 2 (Sphagnum-small sedge communities) are thus more distinct than the differences in $\mathrm{SiO}_{2}$ concentrations (Fig. 3). The concentration of $\mathrm{Fe}$ is independent of water table dynamics and reaches the highest values in brown moss-small and slender sedge communities and in Sphagnumsmall sedge communities (Fig. 3).

$\mathrm{Ca}^{2+}$ was not correlated with either $\mathrm{Mg}^{2+}$ or $\mathrm{pH}$ in the subsurface waters along the present (2007-2009) transects (Fig. 3), while in the surficial waters (2003-2005 data) there was a clear correlation of all the three mentioned above properties and they very well distinguished Sphagnum-vegetation from brown moss-sedge communities (Fig. 5).

Another factor that turned out to be important in separating vegetation types in the CCA analysis is the total shrub and tree layers cover (Fig. 3). This variable is correlated similarly with $1^{\text {st }}$ and $2^{\text {nd }}$ CCA axis (Table 1), thus showing some independence from the 
Table 1 Summary of canonical correspondence analysis (CCA)

\begin{tabular}{|c|c|c|c|c|c|c|}
\hline Axes: & 1 & 2 & & 3 & 4 & Total inertia \\
\hline Eigenvalues & 0.699 & 0.567 & & 0.471 & 0.399 & 5.843 \\
\hline Species-environment correlations & 0.963 & 0.961 & & 0.973 & 0.968 & \\
\hline \multicolumn{7}{|l|}{ Cumulative percentage variance } \\
\hline of species data & 12.0 & 21.7 & & 29.7 & 36.5 & \\
\hline of species-environment relation & 16.3 & 29.6 & & 40.6 & 49.9 & \\
\hline Sum of all eigenvalues & & & & & & 5.843 \\
\hline Sum of all canonical eigenvalues & & & & & & 4.276 \\
\hline \multicolumn{7}{|l|}{ Monte Carlo permutation test } \\
\hline \multicolumn{7}{|c|}{ Test of significance of all canonical axes } \\
\hline \multicolumn{7}{|l|}{ Trace $=4.276$} \\
\hline \multicolumn{7}{|l|}{$F$ ratio $=1.445$} \\
\hline \multicolumn{7}{|l|}{$P$ value $=0.0140$} \\
\hline Axes: & 1 & & 2 & & 3 & 4 \\
\hline \multicolumn{7}{|c|}{ Correlation coefficients of environmental variables with the CCA axes } \\
\hline Min. water level V and VI & 0.677 & & 0.054 & & 0.300 & -0.194 \\
\hline Min. water level VII and VIII & 0.631 & & 0.183 & & 0.384 & -0.296 \\
\hline Max. water level III and IV & -0.507 & & -0.348 & & -0.208 & 0.404 \\
\hline Max. water level IX and X & -0.502 & & -0.241 & & -0.229 & 0.430 \\
\hline $\mathrm{Mg}^{2+}$ & -0.651 & & -0.300 & & -0.181 & -0.146 \\
\hline $\mathrm{Ca}^{2+}$ & 0.195 & & 0.161 & & 0.375 & 0.148 \\
\hline $\mathrm{K}^{+}$ & -0.318 & & -0.268 & & -0.149 & 0.159 \\
\hline $\mathrm{Na}^{+}$ & -0.442 & & -0.209 & & 0.087 & -0.137 \\
\hline $\mathrm{pH}$ & -0.192 & & -0.433 & & 0.160 & -0.063 \\
\hline Total Fe & -0.338 & & 0.528 & & -0.299 & -0.203 \\
\hline Dissolved $\mathrm{SiO}_{2}$ & -0.585 & & -0.053 & & 0.028 & 0.015 \\
\hline $\mathrm{N}-\mathrm{NH}_{4}{ }^{+}$ & 0.500 & & 0.113 & & -0.093 & 0.010 \\
\hline $\mathrm{N}-\mathrm{NO}_{3}{ }^{-}$ & 0.035 & & 0.251 & & 0.231 & 0.180 \\
\hline $\mathrm{P}-\mathrm{PO}_{4}{ }^{3-}$ & 0.051 & & 0.240 & & -0.182 & -0.301 \\
\hline $\mathrm{SO}_{4}^{2-}$ & 0.143 & & 0.163 & & 0.565 & 0.100 \\
\hline $\mathrm{Cl}^{-}$ & -0.117 & & -0.007 & & 0.278 & 0.024 \\
\hline Shrub/tree cover & 0.594 & & -0.454 & & 0.464 & -0.284 \\
\hline
\end{tabular}

correlated with 1st CCA axis minimal water level variables.

\section{Discussion}

The studied chemical parameters are relatively homogeneous in the whole mire and do not have a major impact on vegetation patterns (Table 2, Fig. 3). Our results indicate that groundwater at $30-50 \mathrm{~cm}$ depth is everywhere equally alkaline. One could perhaps record higher differences by using water from the moss layer (,squeezed water” - Hájkova \& Hájek, 2004), which is chemically more differentiated due to processes occurring in the surface layer of the mire, e.g. cation exchange by Sphagnum species (Clymo, 1964; Vitt, 2000). If the squeezed water was analysed, comparison of all the vegetation types would be difficult, because of comparing waters from different depths due to significant differences in water table levels between vegetation types (e.g. comparing brown moss-small sedge fens and forest communities). Our results address to the water feeding particular parts of the peatland and deal to less extent with small-scale 


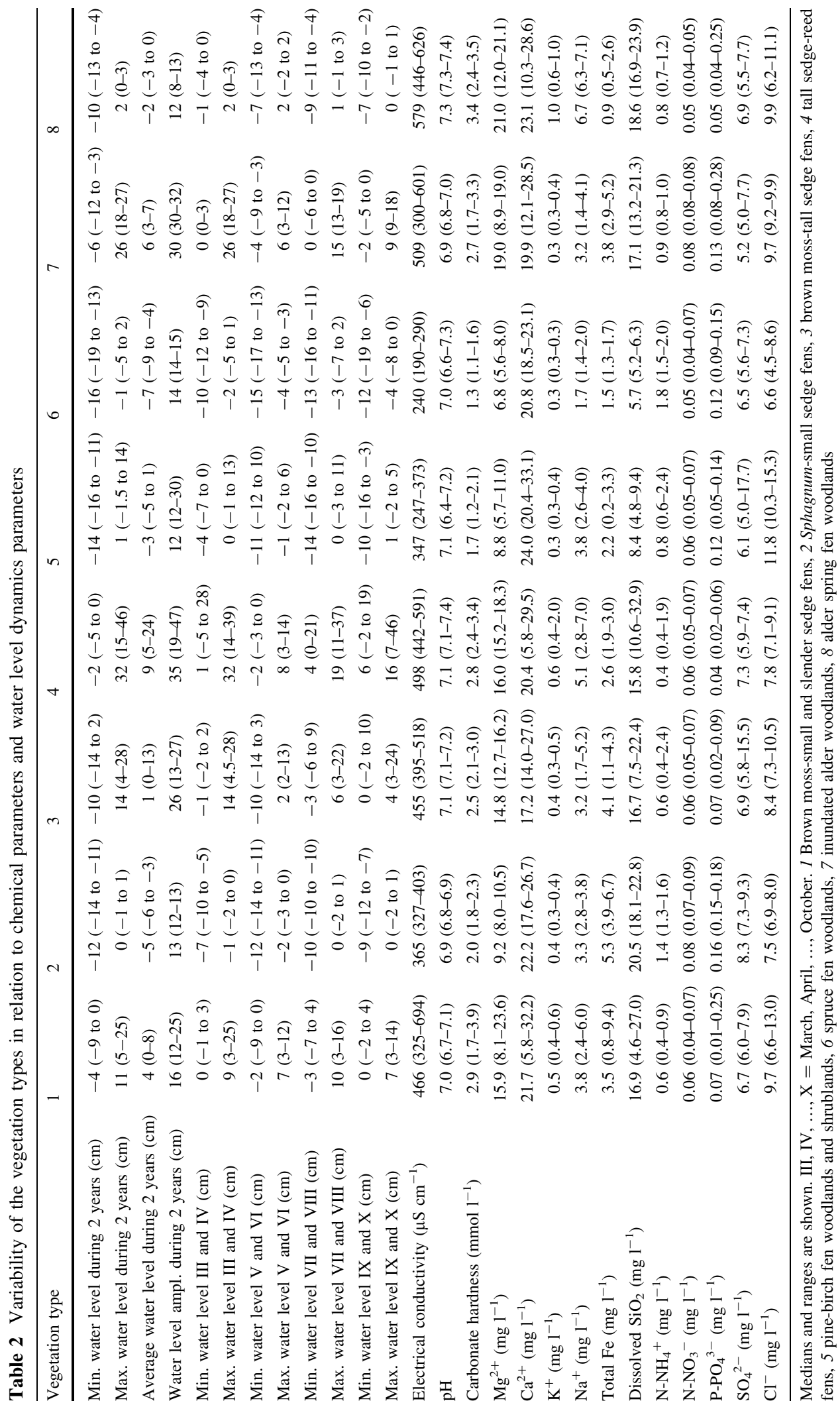



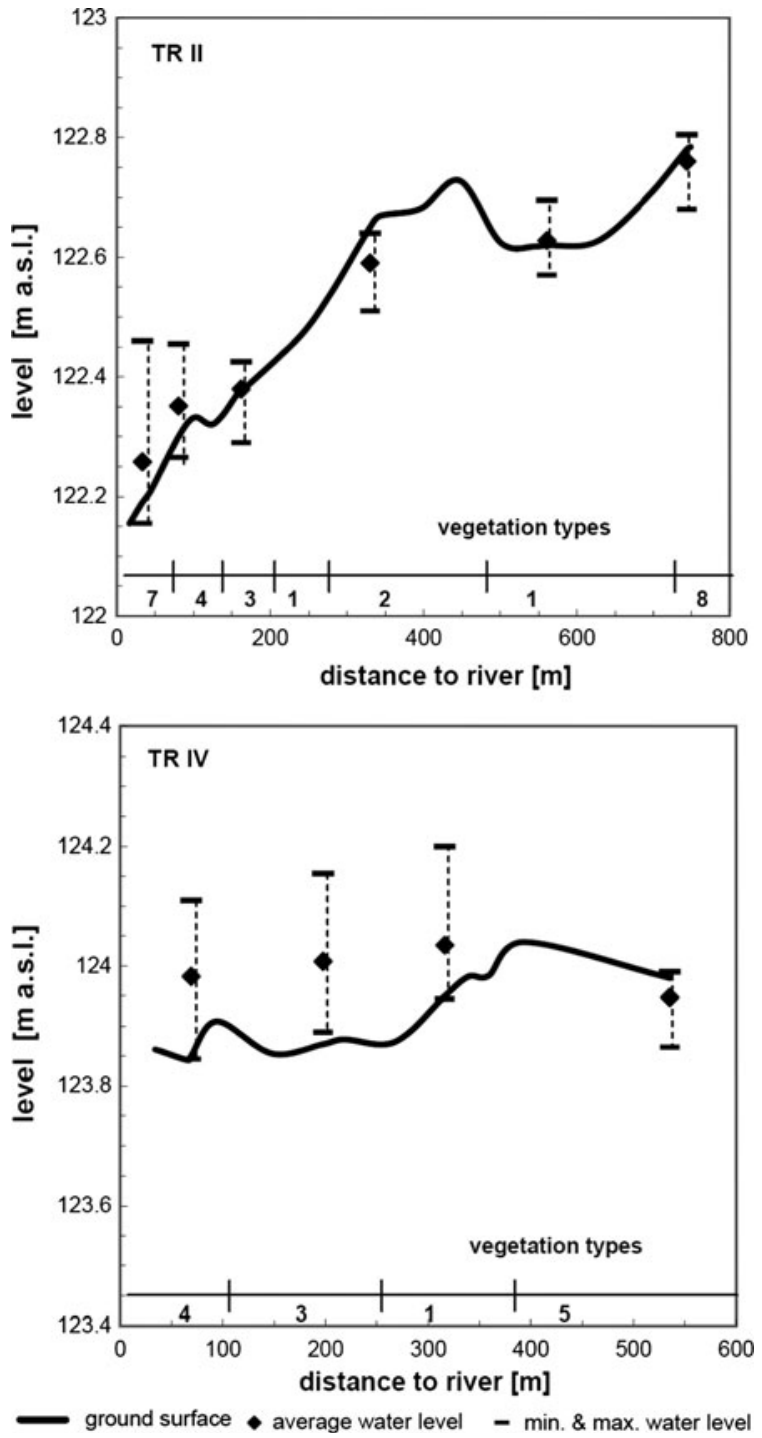

Fig. 4 Mire surface level along two transects (TR II and TR IV), water level dynamics in sampling points along the transects and vegetation types along the transect ( 1 brown moss-small and slender sedge fens, 2 Sphagnum-small sedge fens, 3 brown moss-tall sedge fens, 4 tall sedge-reed fens, 5 pine-birch fen woodlands and shrublands, 7 inundated alder woodlands, 8 alder spring fen woodlands)

processes of the uppermost peat layer. These processes are most important in explaining variation within open moss-sedge communities (Fig. 5). Calcium concentrations are negatively correlated with $\mathrm{Mg}^{2+}$ concentrations and $\mathrm{pH}$ values in the subsurface waters along the present (2007-2009) transects (Fig. 3). In our opinion, this result shows primarily that the $\mathrm{Ca}^{2+}$ concentrations in these waters are quite uniform in the

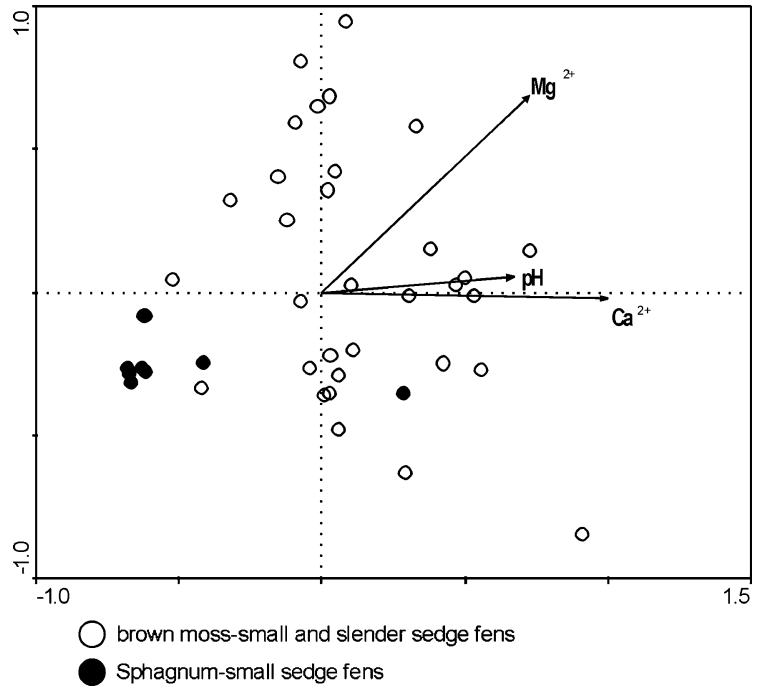

Fig. 5 Principal component analysis of chosen vegetation relevés from open brown moss/Sphagnum-small sedge fens in the Rospuda valley. Eigenvalues: I, 0.988; II, 0.012; III, 0.000; IV, 0.000

scale of the whole peatland (Table 2), rather than they reflect true negative correlation.

When we analysed the chemical parameters jointly with the data on seasonal water level dynamics, an important role of iron in controlling vegetation patterns was revealed (Fig. 3). This might be due to its toxicity (Snowden \& Wheeler, 1993), creation of little-soluble compounds with $\mathrm{PO}_{4}{ }^{3-}$ in oxidation conditions (De Mars \& Wassen, 1999) (which limits phosphorous availability to plants, c.f. Wassen \& Barendregt, 1992; Tyler, 2003), as well as its effects on water transparency. Yet, a significant role of this element in controlling mire vegetation patterns has rarely been pointed out (but see Snowden \& Wheeler, 1993; Anderson et al., 1995; Mullen et al., 2000; Tahvanainen et al., 2002; Hájek et al., 2006; Pawlikowski, 2008). Tahvanainen et al. (2002) observed correlation of Fe concentration with the mire margin-mire expanse gradient. They associated a higher Fe content on the mire margin then in the middle with decreasing influence of the surface water runoff. In the Rospuda mire, highest Fe content was recorded in the middle part of the open fen vegetation, whereas the lowest concentration was found along the mire margin and close to the river.

Schipper et al. (2007) studied preconditions of vegetation zonation in a natural percolation mire in 
the Ob river valley (western Siberia) and found a similar relation to iron concentration pattern as in the Rospuda mire. The highest values in the "open mire zone" in the middle part of the $\mathrm{Ob}$ mire are related to permanent inundation of mire surface that can be ascribed to a large groundwater flux combined with a gentle slope of the mire surface and obstruction of surficial mire water flow by the peat ridges, which run parallel to the $\mathrm{Ob}$ River. The obstruction and stagnation of water flow are illustrated by the high iron concentrations of the surficial mire water as a result of $\mathrm{Fe}^{2+}$ oxidation and the precipitation of its compounds on the mire surface.

High concentrations of $\mathrm{Mg}^{2+}$ and $\mathrm{SiO}_{2}$ confirm the groundwater origin of water feeding a mire (Tahvanainen et al., 2002). More distinct differences in $\mathrm{Mg}^{2+}$ than in $\mathrm{SiO}_{2}$ concentrations between vegetation types 1 and 2 could be explained by the process of cation uptake by Sphagnum species (Clymo, 1964; Gorham et al., 1985) - sphagna take up $\mathrm{Mg}^{2+}$ ions but do not take up $\mathrm{SiO}_{2}$. Lower concentrations of $\mathrm{Mg}^{2+}$ and $\mathrm{SiO}_{2}$ within spruce- and pine-birch fen woodlands point to lower influence of groundwater and to a more important role of rainwater within these vegetation types. High content of magnesium in the subsurface water in the mire reflects the composition of ground water in the whole region of north-eastern Poland (Oficjalska et al., 2004).

The seasonal dynamics of water table was revealed as the important factor underlying vegetation patterns in the Rospuda valley fen (Fig. 3). The importance of water level gradient has been shown by numerous authors from various parts of the world (e.g. Martin \& Bouchard, 1993; Yabe \& Onimaru, 1997; Navrátilova \& Navrátil, 2005).

In the Rospuda valley, the zones with the lowest water level are occupied by forests and Sphagnum vegetation. Preconditions of Sphagnum-dominated poor fen communities are thus similar to those described by Giller \& Wheeler (1988), who stated that poor fens develop in non-flooded, temporarily moderately drying sites. They explain that such water conditions may result from vertical movements of the mire surface, which prevent flooding during wet seasons and larger drainage during dry seasons. Lamers et al. (1999) explain these mire movements by the presence of gases originating in the peat, which cause its buoyancy. Such sites offer good conditions for the development of peat mosses (e.g. Sphagnum teres), which can tolerate alkaline fen conditions (Daniels \& Eddy, 1990). They acidify the environment (Clymo, 1964; Gorham et al., 1985), facilitating the establishment of other Sphagnum species, finally leading to the poor fen stage. The remaining vegetation types are characterised by a higher water level, which in the brown moss-small and slender sedge communities is relatively stable during the whole year, whereas brown moss-tall sedge communities, tall sedge-reed fens and alder woodlands develop in zones with spring or autumn surface flooding or inundation (Fig. 3). The differences in the seasonal dynamics of water level are thus related to the position of each vegetation zone in mire cross section (Fig. 4). The affinities of tall sedge and reed communities to surface flooding, in contrast to brown mosssmall and slender sedge communities are known from other river valleys, e.g. Biebrza (Wassen et al., 1992).

Similarly, Schipper et al. (2007) proved that differences in peat and surficial mire water chemistry occur in the $\mathrm{Ob}$ river valley, but are small and not reflected in vegetation characteristics. The vegetation characteristics of the study site can largely be explained by hydrological processes. Despite the large flux of discharging groundwater close to the terrace scarp, the steep slope of the "marginal mire zone" leads to relatively dry conditions. This results in higher mineralization rates and eutrophication. The eutrophic and relatively dry conditions give rise to the development of highly productive, species-poor forest or reed vegetation. In the "open mire zone" in the middle part of the mire permanent inundation of the mire surface facilitates the presence of sedges and prevents the establishment of trees and shrubs, as the latter require (at least periodically) water levels below the surface (Wassen et al., 1992). In the "forested mire zone" close to the river, the steeper slope of the mire surface and the proximity of the river cause draining conditions. The draining conditions prevent constant inundation of the mire surface and enable trees and shrubs to establish in this zone.

Apart from the water level dynamics, another factor turned out to be important in distinguishing vegetation types - shading expressed by total shrub and tree layers cover (Fig. 3). In this study we did not investigate the influence of light availability correlated with productivity of the herb layer, which could also be an important factor controlling non-forest fen vegetation patterns (Kotowski \& Van Diggelen, 2004). However, 
light availability in the distinguished vegetation types could be estimated on the basis of results from similar vegetation types, obtained by Kotowski \& Van Diggelen (2004). If only hydrologically intact fen system, like the Rospuda mire, is considered, light availability seems to be correlated with water level dynamics, unlike in the case when both undisturbed und drained fens were considered together (Kotowski \& Van Diggelen, 2004). In the Rospuda mire, the tall sedge-reed fens zone close to the river, characterised by high productivity and low light availability, is connected with high water level amplitudes, draining conditions, higher peat mineralization and eutrophication; while brown moss-small and slender sedge vegetation (low productivity, high light availability) is connected with stable high water level.

Summing up, besides some regionally characteristic features (e.g. high $\mathrm{Fe}$ and $\mathrm{Mg}^{2+}$ contents in ground water), the results obtained in the Rospuda valley show similarity to those from the natural Siberian mire (differences in subsurface water chemistry are small and the vegetation characteristics can largely be explained by hydrological processes) which is another argument supporting the notion of Rospuda mire as an unique in Europe well-preserved groundwater-fed percolation fen. The peatlands of Rospuda valley, with undisturbed ecological processes, can thus be regarded as a unique reference system for European percolation fens.

Acknowledgements The paper is dedicated to people who contributed to saving the Rospuda mire against destruction by a motorway construction across it. Special acknowledgments to the following (in alphabetical order): Adam Bohdan (Workshop for All Beings, Podlasie Branch), Dr. Przemysław Chylarecki (Polish Society for the Protection of Birds), Dr. Rudy van Diggelen (Society for Ecological Restoration Europe), Małgorzata Górska (Polish Society for the Protection of Birds), Dr. Hans Joosten (International Mire Conservation Group), Dr. Wiktor Kotowski (Wetland Conservation Centre), Dr. Maciej Muskat (Greenpeace Poland), Prof. Dr. Hab. Maciej Nowicki (Polish Minister of Environment), Adam Wajrak (Gazeta Wyborcza), Dr. Marta Majka Wiśniewska (World Wildlife Found Poland, CEE Bankwatch Network).The research was financed by Polish Ministry of Science and Higher Education Grant no. N304 010 31/0414.

Open Access This article is distributed under the terms of the Creative Commons Attribution Noncommercial License which permits any noncommercial use, distribution, and reproduction in any medium, provided the original author(s) and source are credited.

\section{References}

Anderson, D. S., R. B. Davis \& J. A. Janssens, 1995. Relationships of bryophytes and lichens to environmental gradients in Maine peatlands. Vegetatio 120: 147-159.

Bragazza, L., H. Rydin \& R. Gerdol, 2005. Multiple gradients in mire vegetation: a comparison of a Swedish and an Italian bog. Plant Ecology 177: 223-236.

Braun-Blanquet, J., 1951. Pflanzensoziologie. 2. Aufl. Springer, Wien.

Clymo, R. S., 1964. The origin of acidity in Sphagnum bogs. The Bryologist 67: 427-431.

Daniels, R. E. \& A. Eddy, 1990. Handbook of European Sphagna. Institute of Terrestrial Ecology, London.

De Mars, H. \& M. J. Wassen, 1999. Redox potentials in relation to water levels in different mire types in the Netherlands and Poland. Plant Ecology 140: 41-51.

Du Rietz, G. E., 1949. Huvudenheter och huvudgränser i svensk myrvegetation. Svensk Botanisk Tidskrift 43: 274-309.

Giller, K. E. \& B. D. Wheeler, 1988. Acidification and succession in a flood-plain mire in the Norfolk Broadland, UK. Journal of Ecology 76: 849-866.

Gorham, E., S. J. Eisenrich, J. Ford \& M. V. Santelmann, 1985. The chemistry of bog waters. In Stumm, W. (ed.), Chemical Processes in Lakes. John Wiley, New York: 339-363.

Hájek, M., M. Horsak, P. Hájková \& D. Dítě, 2006. Habitat diversity of central European fens in relation to environmental gradients and an effort to standardise fen terminology in ecological studies. Perspectives in Plant Ecology, Evolution and Systematics 8: 97-114.

Hájková, P. \& M. Hájek, 2004. Bryophyte and vascular plants responses to base-richness and water level gradients in Western Carpathian Sphagnum-rich mires. Folia Geobotanica 39: 335-351.

Kondracki, J., 2001. Geografia Regionalna Polski. Wydawnictwo Naukowe PWN, Warszawa.

Kotowski, W. \& R. Van Diggelen, 2004. Light as an environmental filter in fen vegetation. Journal of Vegetation Science 15: 583-594.

Lamers, L. P. M., C. Farhoush, J. M. van Groenendael \& J. G. M. Roelofs, 1999. Calcareous groundwater raises bogs; the concept of ombrotrophy revisited. Journal of Ecology 87: 639-648.

Malmer, N., 1986. Vegetational gradients in relation to environmental conditions in northwestern European mires. Canadian Journal of Botany 64: 375-383.

Martin, J. \& A. Bouchard, 1993. Riverine wetland vegetation: importance of small-scale environmental variation. Journal of Vegetation Science 4: 609-620.

Mirek, Z., H. Piękoś-Mirkowa, A. Zając \& M. Zając, 2002. Flowering plants and pteridophytes of Poland. A checklist. In Mirek, Z. (ed.), Biodiversity of Poland 1. W. Szafer Institute of Botany, Polish Academy of Science, Kraków.

Mullen, S. F., J. A. Janssens \& E. Gorham, 2000. Acidity of and the concentrations of major and minor metals in the surface waters of bryophyte assemblages from 20 North 
American bogs and fens. Canadian Journal of Botany 78: $718-727$.

Navrátilova, J. \& J. Navrátil, 2005. Vegetation gradients in fishpond mires in relation to seasonal fluctuations in environmental factors. Preslia 77: 405-418.

Ochyra, R., J. Żarnowiec \& H. Bednarek-Ochyra, 2003. Census Catalogue of Polish Mosses. Biodiversity of Poland, Vol. 3. W. Szafer Institute of Botany, Polish Academy of Science, Kraków.

Oficjalska, H., B. Krawczyńska \& Z. Ćwiertnicka, 2004. Objaśnienia do Mapy Hydrogeologicznej Polski w skali 1:50 000, Arkusz Augustów (0147). Państwowy Instytut Geologiczny, Warszawa.

Økland, R. H., T. Økland \& K. Rydgren, 2001. A Scandinavian perspective on ecological gradients in north-west European mires: reply to Wheeler and Proctor. Journal of Ecology 89: 481-486.

Pawlikowski, P., 2008. Syntaksonomiczne i siedliskowe zróżnicowanie roślinności mechowisk i minerotroficznych mszarów w polskiej części Pojezierza Litewskiego. PhD Thesis, Faculty of Biology, University of Warsaw, Warsaw.

Pawlikowski, P., F. Jarzombkowski, E. Jabłońska \& S. Kłosowski, 2010. Torfowiska nad dolną Rospudą. In Obidziński, W. (ed.), Z Mazowsza na Wileńszczyznę. Zróżnicowanie i ochrona szaty roślinnej pogranicza Europy Środkowej i Północno-Wschodniej. Polskie Towarzystwo Botaniczne Zarzad Główny, Warszawa: 341-357.

Schipper, A. M., R. Zeefat, F. Tanneberger, J. P. van Zuidam, W. Hahne, S. A. Schep, S. Loos, W. Bleuten, H. Joosten, E. D. Lapshina \& M. J. Wassen, 2007. Vegetation characteristics and eco-hydrological processes in a pristine mire in the $\mathrm{Ob}$ River valley (Western Siberia). Plant Ecology 193: 131-145.

Sjörs, H., 1950. Regional studies in North Swedish mire vegetation. Botaniska Notiser 103: 173-222.

Snowden, R. E. D. \& B. D. Wheeler, 1993. Iron toxicity to fen plant-species. Journal of Ecology 81: 35-46.

Succow, M. \& H. Joosten, 2001. Landschaftsökologische Moorkunde. 2. Aufl. Schweizerbart, Stuttgart.

Tahvanainen, T., T. Sallantaus, R. Heikkilä \& K. Tolonen, 2002. Spatial variation of mire surface water chemistry and vegetation in northeastern Finland. Annales Botanici Fennici 39: 235-251.

Ter Braak, C. J. F., 1986. Cannonical correspondence analysis: a new eigenvector technique for multivariate direct gradient analysis. Ecology 67: 1167-1179.

Ter Braak, C. J. F. \& P. Šmilauer, 1998. CANOCO Reference Manual and User's Guide to Canoco for Windows. Software for Cannonical Community Ordination (version 4). Centre for Biometry Wageningen (Wageningen, NL) and Microcomputer Power Ithaca, New York.

Tyler, G., 2003. Some ecophysiological and historical approaches to species richness and calcicole/calcifuge behaviour-contribution to a debate. Folia Geobotanica 38: 419-428.

Van Diggelen, R., B. Middleton, J. Bakker, A. Grootjans \& M. Wassen, 2006. Fens and floodplains of the temperate zone: Present status, threats, conservation and restoration. Applied Vegetation Science 9: 157-162.

Verhoeven, J. T. A., A. Keuter, R. Van Logtestijn, M. B. Van Kerkhoven \& M. Wassen, 1996. Control of local nutrient dynamics in mires by regional and climatic factors: a comparison of Dutch and Polish sites. Journal of Ecology 84: 647-656.

Vitt, D. H., 2000. Peatlands: ecosystems dominated by bryophytes. In Shaw, A. J. \& B. Goffinet (eds), Bryophyte Biology. Cambridge University Press, Cambridge: 312-343.

Wassen, M. J. \& A. Barendregt, 1992. Topographic position and water chemistry of fens in a Dutch river plain. Journal of Vegetation Science 3: 447-456.

Wassen, M. J., A. Barendregt, A. Pałczyński, A. J. T. De Smidt \& H. De Mars, 1992. Hydro-ecological analysis of the Biebrza mire (Poland). Wetlands Ecology and Management 2: 119-134.

Wheeler, B. D. \& C. F. Proctor, 2000. Ecological gradients, subdivisions and terminology of north-west European mires. Journal of Ecology 88: 187-203.

Yabe, K. \& K. Onimaru, 1997. Key variables controlling the vegetation of a cool-temperate mire in northern Japan. Journal of Vegetation Science 8: 29-36. 